\title{
COMO OS JUÍZES DECIDEM? NOTAS E APONTAMENTOS SOBRE O COMPORTAMENTO NA DECISÃO JUDICIAL
}

\author{
HOW DO JUDGES MAKE THEIR DECISIONS? NOTES ABOUT THE BEHAVIOR \\ IN LEGAL DECISIONS
}

\author{
${ }^{1}$ Rafael Guimarães Abras Oliveira
}

\begin{abstract}
RESUMO
O presente ensaio tem como objetivo apresentar, basicamente, três perspectivas que procuram explicar e descrever o comportamento judicial: o ponto de vista político, o ponto de vista jurídico e o ponto de vista realista. Do ponto de vista político, o direito é visto como um instrumento pelo qual se atinge determinado fim e o sujeito é apenas o agente que dá ensejo à finalidade que repercute na coletividade. Como se atinge determinado fim? Do ponto de vista jurídico, embora pela política se consolide os instrumentos necessários à ordem jurídica, esta não deve interferir na política e sim ser construída conforme normas e princípios institucionalizados. A ótica do dever ser precede o sujeito, de modo que o sujeito, do ponto de vista jurídico, é aquele que deve ou não deve fazer algo. Tanto do ponto de vista político quanto do ponto de vista jurídico partem do sujeito abstrato, do sujeito que age conforme manda sua vontade (política) ou a norma jurídica (direito). Por isso que a terceira perspectiva, o ponto de vista realista, descreve o sujeito real, enquanto homem físico inserido na ordem social, comporta-se nas decisões judiciais. Assim, o presente ensaio apresenta notas e apontamentos do comportamento judicial nas perspectivas descritas.
\end{abstract}

Palavras-chave: Comportamento, Decisão, Juiz

\begin{abstract}
The aim of this paper is to present, basically, the judge's behavior throught three different perspectives: the political, the legal and the realistic points of view. From the political point of view, Law is seen as an instrument used to get to a certain goal, and the subject is only the agent that causes consequences on the community. How to get to a certain goal? From the legal point of view, even though it is possible to, using policy, reinforce the necessary instruments of the legal order,it should not interfere in policy, but should be built according to institucionalized principles and law. The perspective of what should be precedes the subject, in a way that the subject, from the legal point of view, is the one that should or shouldn't do something. Both political and legal point of view start from the abstract subject, the subject that acts as his will (policy) or the legal law (Law). This is why the third perspective, the realistic point of view, describes the real subject, while the real man, inserted in the social order, acts in the legal decisions. Because of that, the present paper presents notes about the judge's behavior in the three perspectives shown.
\end{abstract}

Keywords: Behavior, Decision, Judge

1 Mestrando em Direito pela Universidade Federal de Minas Gerais. Universidade Federal de Minas Gerais UFMG, Belo Horizonte, Minas Gerais. Brasil - E-mail: rafaelabras@yahoo.com.br 


\section{Introdução \\ 1.1}

Ivan Ilitch é um juiz à beira da morte que revê sua história bem sucedida buscando encontrar algum sentido. Desde a infância, atraído pelas altas posições sociais, "tal como a mariposa pela luz" (TOLSTOI, 2006, p. 12), o personagem de Tólstoi reflete sobre suas escolhas e posições ao longo da vida: sua submissão a um suposto legalismo, disfarçado de carreirismo, fora um erro imprudente. $\mathrm{O}$ direito, indica o escritor russo, não pode ser aplicado de forma mecânica.

O retrato da angústia de Ivan Ilitch serve para introduzir o problema a ser tratado no presente artigo: como os juízes julgam? Ou, em outros termos, o que influencia a decisão de um juiz? Buscar um sentido para o fato, aplicar formalmente a lei, estrategicamente se posicionar para não prejudicar a imagem e a carreira traçada dentro da instituição? Aspectos que não são ignorados por quem leva o direito a sério e que direta e efetivamente interferem na decisão. Através de autoenganos, Ilitchs decidiram e decidem, sem levar em consideração uma série de fatores que influenciam as decisões.

1.2

Poder-se-ia destacar, basicamente, três perspectivas que procuram explicar e descrever o comportamento judicial: o ponto de vista político, o ponto de vista jurídico e o ponto de vista realista. Cada qual a sua maneira destaca um elemento, sem, contudo, repudiar os demais, sendo, acima de tudo, perspectivas que privilegiam determinado elemento. Três são, portanto, os elementos através dos quais se partem a análise, a saber: a política, o direito e o sujeito.

Do ponto de vista político, o direito é visto como um instrumento pelo qual se atinge determinado fim e o sujeito é apenas o agente que dá ensejo à finalidade que repercute na coletividade. "Como se atinge determinado fim?"

Do ponto de vista jurídico, embora pela política se consolide os instrumentos necessários à ordem jurídica, esta não deve interferir na política e sim ser construída conforme normas e princípios institucionalizados. A ótica do dever ser precede o sujeito, de modo que o sujeito, do ponto de vista jurídico, é aquele que deve ou não deve fazer algo.

Tanto do ponto de vista político quanto do ponto de vista jurídico partem do sujeito abstrato, do sujeito que age conforme manda sua vontade (política) ou a norma jurídica (direito). Por isso que a terceira perspectiva, o ponto de vista realista, descreve o sujeito real, 
enquanto homem físico inserido na ordem social, comporta-se nas decisões judiciais.

\section{As perspectivas do comportamento judicial}

\subsection{Ponto de vista político}

Otto von Bismarck dizia "política é a arte do possível". E no estudo do comportamento judicial, o termo "política" adquire muitos possíveis significados. Posner destaca que "política" pode se referir a julgamentos que refletem a lealdade a determinado partido político ou a convicção a determinada ideologia; pode ainda descrever decisões técnicas que buscam o meio mais eficiente para o fim acordado e que tem impacto perante a política pública; também pode ser considerado "político" o juiz que decida com base em interesses próprios, como a prática de venda de sentenças, que produz resultados tanto institucionalmente na jurisprudência quanto na arena pública (POSNER, 2008, p.10).

Em termos políticos destacamos duas escolas: o modelo atitudinal e o modelo estratégico. O primeiro tem em vista os fins, ao agir conforme uma convicção previamente explicitada, conquanto no segundo prevalece a análise dos meios para chegar a determinado fim, o qual permanece oculto e individualizado. Não sendo necessariamente incompatíveis, os dois modelos podem emergir concomitantemente e são caracterizados a seguir.

\subsubsection{O modelo atitudinal:}

O modelo atitudinal parte de uma premissa simples: o julgador está sujeito a julgar consoante sua inclinação ideológica. Comprovada por inúmeras pesquisas desenvolvidas tanto na ciência política quanto na psicologia, a influência da ideologia no raciocínio decisório parece ser maior do que se pensa. De acordo com o modelo atitudinal, os juízes tomam decisões “considerando os fatos do caso à luz das suas atitudes e valores ideológicos" (SEGAL e SPAETH, 1993, p.72): sugere-se que os juízes teriam determinadas preferências políticas pessoais que serviriam como bons indicadores de suas futuras decisões, sobretudo em casos sem precedentes anteriores ou que envolvam questionamentos morais na sociedade.

Os atitudinalistas argumentam que os juízes são funcionários do governo, recebem um salário fixo e não têm interesse econômico nas decisões, de modo que julgam segundo suas convicções e projeções de seus ideais de justiça. O papel político influenciaria, portanto, os 
juízes na construção de precedentes que refletissem suas posições ideológicas.

Como a maior parte dos defensores do modelo atitudinal estão nos Estados Unidos, é comum existir a classificação dos juízes como liberais ou conservadores, associados, respectivamente, mesmo que de forma indireta, ao Partido Democrata e ou Partido Republicano. Para indicar quais juízes teriam ou não inclinação para julgar conforme orientações partidárioideológicas, os estudiosos partem na premissa de que o presidente indicará um juiz que tenha afinidade com seu partido político. Vale lembrar que, nos EUA, vários outros cargos de juiz além dos da Suprema Corte são preenchidos por indicação presidencial. Um exemplo utilizado para destacar a força do modelo atitudinal é o julgamento da Suprema Corte americana no caso Bush v Gore. No controverso desdobramento do impasse na recontagem dos votos do estado da Flórida nas eleições presidenciais de 2000, a decisão da corte foi tomada por cinco votos a quatro: os cinco votos vencedores eram de indicados por Presidentes republicanos, e os dois únicos indicados por democratas no tribunal ficaram do lado vencido (FERREIRA, 2013, p. 10).

O modelo atitudinal não foi isento de críticas. Que existiria uma sobrelevação do impacto ideológico; que os estudos não distinguiriam claramente quais e como os votos são politicamente motivados ou de que os interesses dos juízes são exclusivamente políticos; que a indicação presidencial não significaria compromisso dos juízes com a orientação partidária ${ }^{1}$ - tais são as críticas mais frequentes ao modelo atitudinalista, críticas que não foram obliteradas pelo segundo modelo político do comportamento dos juízes, o modelo estratégico, analisado a seguir.

\footnotetext{
1 Earl Warren, por exemplo, presidiu a Corte Americana entre 5 de outubro de 1953 e 23 de junho de 1969, foi nomeado por um presidente republicano e durante o exercício no cargo, o Supremo Tribunal norte-americano foi marcado por um ativismo que contestou a segregação racial e ampliou os direitos civis.
} 


\subsubsection{O modelo estratégico:}

Marx bradava sua crítica integral das mentes, sua teoria das máscaras sob o título de "A Ideologia Alemã": "Até agora, os homens sempre tiveram ideias falsas a respeito de si mesmos, daquilo que são ou deveriam ser (...) Criadores inclinaram-se diante das próprias criações" (MARX e ENGELS, 1998, p.03). O homem ingênuo deveria colocar suas convicções no tribunal da razão e questionar até que ponto determinada crença era ou não uma convenção destinada a um fim posto por outrem. Nesse sentido, a ideologia seria uma consciência que ainda não é ciente de si ou não questiona as bases sob qual está assentada.

O modelo estratégico pressupõe a crítica da ideologia, sabe que o juiz pode não ser tão sincero e leal a suas supostas convicções como é aparentado. Dentro de uma instituição colegiada, o juiz levaria em conta a participação, reação e negociação com seus pares em um tribunal. Sabendo que decisões colegiadas requerem um mínimo de consenso e de que podem incidir de maneira ampla na sociedade, o modelo estratégico admite uma flexibilidade e a ponderação em detrimento da reação dos outros ante a decisão almejada. Não só vislumbrando a aceitação ou rejeição da opinião pública, mas também a reputação perante os advogados, os colegas de trabalho e a comunidade acadêmica, os juízes decidiriam com base em um raciocínio de utilidade, um raciocínio instrumental, oposto ao raciocínio ideológico.

Epstein e Knight (1998, p. xiii) destacam que:

Juízes podem buscar essencialmente objetivos jurídicos, mas eles não são personagens simples que fazem escolhas baseadas meramente em suas preferências políticas. Ao invés disso, juízes são atores estratégicos, que percebem que sua capacidade de alcançar seus objetivos depende do modo como consideram as preferências de outros, das escolhas que eles esperam que outros façam, e do contexto institucional em que eles atuam. Em outras palavras, as escolhas podem ser melhor explicadas como um comportamento estratégico, não somente como respostas a ideologia pessoal ou a jurisprudência apolítica.

Segundo a literatura estratégica, poder-se-ia destacar três elementos principais no comportamento judicial: o fim, o modo e a relação com outros agentes. Que as ações dos juízes são direcionadas para a consecução de determinados objetos; que o modo de agir é estratégico; e que os juízes não estão sozinhos para decidir, mas interagem entre os juízes, entre um tribunal e outros poderes, e entre um tribunal e o povo. 
O comportamento estratégico releva as circunstâncias e a relação com outros agentes. Se o comportamento sincero pressupõe um terreno livre de influência em que o juiz julga conforme o seu melhor entendimento, o comportamento estratégico suspende esse lócus ideal e supõe um agir com o "intuito de garantir um resultado mais próximo do que o juiz prefere" (FRIEDMAN apud FERREIRA, 2013, p.16). Nesse sentido, evitar lutas e desgastes nos quais se sabe que não irá se sair vencedor, politicamente ceder quando não é possível se impor e se impor quando convém não ceder, tudo isso o agir estratégico deve levar em conta e também ter a consciência de que "lutas pelo poder no interior de corpos políticos sempre são também lutas por primazias" entre "indivíduos ambiciosos acompanhados de seus séquitos; a arte do político encerra, por isso, o procedimento de indenização dos perdedores” (SLOTERDIJK, 2012, p. 33). Por isso, para cada decisão que contrarie a convicção de uns hoje, amanhã os contrariados podem reformulá-la ou utilizarem a derrota ante a primeira decisão para barganhar a vitória num próximo julgamento - o voto vencido de ontem pode ser o voto vencedor de amanhã.

\subsection{Ponto de vista jurídico:}

Subsumir o fato à norma e decidir e interpretar o caso tendo em vista a qualidade na argumentação e o respeito com a moralidade e história institucional, no sentido de tanto levar em conta a tradição e olhar o passado para reescrever o futuro, quanto de não se prender à tradição e se for o caso consolidar novos entendimentos, materialmente adequados e justificados, tendo em vistas novas demandas e a possibilidade ampliativa do direito. É o que basicamente Dworkin, Alexy, Perelman, e outros tantos expoentes de teorias argumentativas do direito procuram defender e idealizar. É possível e preciso sofisticar, refinar a percepção e, sobretudo, saber distinguir os limites da possibilidade da atuação jurídica.

Saliente-se, contudo, que teorias jurídicas contemporâneas já não são ingênuas (ou cínicas) o suficiente para pressupor uma distinção radical entre moralidade e direito, como apregoavam os positivistas desde o século XIX. Tampouco sustentam que a tomada de decisão deve ser produto de uma análise imparcial e fundamentada na mera aplicação da lei, da doutrina ou da jurisprudência aos fatos de determinado caso.

As teorias jurídicas contemporâneas são mais sofisticadas a ponto de se propor a responder qual seria o papel do juiz dentro de uma sociedade que compartilha certos valores e tem em vista a construção de um referencial ético. Dworkin, por exemplo, concebe o direito 
como integrado não somente por regras positivadas, mas composto também por princípios, os quais, embora não criados deliberadamente, existem e mantêm uma relação com as regras, tanto na formação quanto na justificação da existência e vigência das regras.

Nesse contexto, a distinção entre argumentos de princípio e argumentos de política feita por Ronald Dworkin serve para entender quais os enfoques da decisão judicial e onde a decisão judicial deve se situar. O jusfilósofo afirma:

\begin{abstract}
Os argumentos de política tentam demonstrar que a comunidade estaria melhor, como um todo, se um programa particular fosse seguido. São, nesse sentido especial, argumentos baseados no objetivo. Os argumentos de princípio afirmam, pelo contrário, que programas particulares devem ser levados a cabo ou abandonados por causa de seu impacto sobre pessoas específicas, mesmo que a comunidade como todo fique consequentemente pior. Os argumentos de princípio são baseados em direitos (DWORKIN, 2005, p. IX).
\end{abstract}

Quando o argumento versar sobre políticas públicas, sobre qual seria a melhor estratégia para satisfazer o interesse coletivo através de metas, por exemplo, a erradicação da fome ou a alfabetização da população, estar-se-ia diante de argumentos de política (DWORKIN, 2003, p. 475). Por outro lado, quando a questão envolver a proteção a direitos fundamentais do indivíduo, como, por exemplo, o acesso de afrodescendentes ao ensino universitário ${ }^{2}$, argumentos de princípio deveriam ser aplicados. E é por meio destes que é formada a decisão judicial.

Inicialmente, o argumento de política é utilizado para determinar quais são os direitos em questão criados pelo Legislativo e qual âmbito de incidência seria relativo ao caso. Mas, para a interpretação dos precedentes e a construção da decisão, o juiz utilizará de argumentos de princípio, tendo em vista sua consubstanciação na ordem efetiva.

Um exemplo é o próprio caso norte-americano Brown v. Board of Education of Topeka (347 U.S. 483) de 1954, em que a Corte Suprema dos Estados Unidos declarou inconstitucional a separação entre estudantes negros e brancos nas escolas públicas. Ao ter a matrícula da filha negada em uma escola pública exclusiva de brancos, o pai da menina negra Linda Brown pleiteou judicialmente. A escola se baseava juridicamente no caso Plessy v. Ferguson, de 1892, no qual a Suprema Corte Americana negou o direito de um negro que reivindicava ter assento no mesmo vagão de trem que os brancos. Tal episódio ficou conhecido por uma frase da sentença que dizia "separados, mas iguais" - brancos e negros eram formalmente considerados iguais, mas deveriam, na prática, permanecer separados.

2 Como por exemplo versou o caso norte-americano Brown v. Board of Education of Topeka, 347 U.S. 483 , em 1954.

Teorias do Direito e Realismo Jurídico| e-ISSN: 2525-9601| Minas Gerais | v. 1 | n. 2 | p. 1 - 19 | Jul/Dez. 2015. 
À época, existiam, portanto, políticas que fomentavam a separação, mas que feriam o princípio da igualdade entre as pessoas, disposta na emenda XIV da Constituição norte-americana. Entre o princípio da norma e a prática política, a Suprema Corte norte-americana baseou sua decisão em um argumento de princípio e decidiu que a segregação racial que ocorria nas escolas públicas era inconstitucional, na medida em que desconsiderava o preceito fundamental da igualdade, devendo ser entendida no caso, como igual consideração e respeito.

\subsection{Ponto de vista realista}

$\mathrm{O}$ realismo jurídico foi um movimento iniciado no inicio do século $\mathrm{XX}$ e tinha a consciência de que o direito, muitas vezes como espelho da filosofia e da teologia, por muito tempo se nutriu de teorias eminentemente metafísicas, deontologias positivistas e continuava buscando a pureza metódica de sua área de atuação, professando a fé no especialismo e criticismo iluminista de que a limitação da área de atuação e a busca dos limites do que se pode conhecer constitui a caminhada fatídica do autoconhecimento da Razão, cujo espírito (Geist) hegelianamente se manifesta, diferenciando-se e repetindo, no decorrer da História.

Que o direito não está somente nas leis, em um mundo ideal e moral, cognitivamente acessível e realizável, mas também presente na vida natural. Que o ser humano não é uma tábula rasa (PINKER, 2004), mas condicionado por genes e meios, de modo que há uma estrutura inerente que permanece resistente às tentativas de domesticação culturais. Que o juiz é um ser humano sujeito a falhas, a variações emocionais e à necessidade de reconhecimento social e que, muitas vezes, mais que se ater à lógica fria e à racionalidade ideal, os julgamentos são condicionados às concepções ideológicas, circunstâncias biológicas e outros fatores extrajurídicos. Todos esses fatores não foram obliterados pelo realismo.

Se na época, no início do século XX, o dominante positivismo jurídico buscava ser o espelho duro e puro da norma, de forma a delimitar os contornos morais e outros traços supostamente extrajurídicos - isto é, que não deveriam influenciar a análise das normas e a decisão a partir delas -, o movimento jurídico realista norte-americano procurava ir à contramão da pureza metódica positivista e, na tentativa de identificar e analisar os elementos que compõem o processo de tomada da decisão judicial, verificava que, entre o fato e a norma, havia muito mais coisas que a vã subsunção. 
Nesse sentido, o realismo jurídico norte-americano partia de um pressuposto não apenas cético, mas também prático: a deontologia, em si mesma, não existe, a letra da lei é morta enquanto não vivificada pela atuação do juiz, de forma que o direito nada mais é que o resultado de interpretações na mente do juiz, o qual, em cada caso concreto, irá dizer o que é e o que não é o direito. Bem verdade que só o common law - sistema em que os precedentes tem grande poder vinculativo nas decisões e que, quando não há precedentes, compete aos juízes criar um novo precedente - era o terreno possível para acolher tal teoria. A novidade, portanto, era o deslocamento do objeto de análise: nem o estritamente comportamento político dos juízes, nem sobre o modo como eles deveriam decidir, mas como eles decidiam, enquanto sujeitos reais diante de um caso concreto.

Ao considerar primeiramente o direito como indeterminado, na medida em que o dever ser era avaliado como uma ilusão, uma ficção orientadora que, na realidade, não significava coisa alguma, os realistas saltavam para fora da esfera jurídica e ousavam apontar que as regras jurídicas não guiavam a tomada de decisão, quando o fato ensejador da decisão não encontra precedente. Para eles, os juízes decidem não segundo o ordenamento jurídico, mas o que se percebe, na maioria dos casos, é o uso instrumental do ordenamento jurídico para uma decisão que foi construída com base em algo diverso do direito. O que os realistas descrevem e concluem é simples: o juiz julga antes de observar o ordenamento jurídico e justifica sua decisão utilizando instrumentalmente elementos contidos no ordenamento jurídico. Primeiro há a resposta ao estímulo dado pelos fatos apresentados e pela necessidade de decidir e só depois há uma racionalização instrumental para justificar a decisão tomada anteriormente: os juízes respondem e só depois refletem.

Para alguns realistas, como Jerome Frank, não apenas o direito era indeterminado, mas também os fatos: determinar os acontecimentos relevantes para análise do caso concreto, interpretar o depoimento das testemunhas, dos réus, interpretar cláusulas de contratos e documentos; tais elementos não seriam objetivos, "eles são o que os juízes pensam que são" (FRANK, 2009, p. 30).

Uma teoria descritiva da decisão judicial não obliteraria, portanto, que há uma relação entre a decisão e a personalidade do juiz. Sendo assim, para os realistas norte-americanos, o "direito pode variar de acordo com a personalidade do juiz que por ventura estiver dentro de um caso qualquer" (FRANK apud TRUCHINER e BRANDO, 2014, p. 176).

Teorias do Direito e Realismo Jurídico | e-ISSN: 2525-9601| Minas Gerais | v. 1 | n. 2 | p. 1 - 19 | Jul/Dez. 2015. 
Notoriamente influenciados pelo naturalismo filosófico, o realismo jurídico vislumbrava que, no momento da decisão, existiria tanto a influência biológica idiossincrática quanto a influência social-ideológica. A resposta do juiz, assim, conteria tanto elementos biológicos quanto sociológicos e o direito, por ser indeterminado, seria determinado por tais fatores extrajurídicos.

Não resta dúvidas que haveria, em tal postura, uma desconsideração amplificada ao modelo jurídico de comportamento judicial, atribuindo a decisão judicial um grau de aleatoriedade e insegurança jurídica desproporcional. Os juízes não só têm vinculação ao dever jurídico como também, em muitas vezes, interpretam o direito tendo em vista suas convicções e estratégias para atingir algo.

Apesar de conclusões aparentemente pueris e metodologias frágeis, o realismo jurídico atentou para o fato de que o sujeito desempenha um papel bem maior do que se supõe. Desde a virada realista, há fortes evidências, corroboradas pela psicologia moral, pela filosofia, pela sociologia e pela ciência política, de que os juízes não decidem de maneira tão racional quanto se deseja ou se imagina e que, atualmente, com o avanço da psicologia contemporânea, a teoria descritiva realista ganha maior fundamentação.

Soma-se a isso a percepção de Dworkin acerca da natureza interpretativa do direito - e consequentemente moral, já que a argumentação moral faz parte do raciocínio interpretativo -, de modo que, perguntar sobre como os juízes julgam é também perguntar sobre como são interpretados e feitos os julgamentos morais. Considerando que questões jurídicas também gravitam em torno do domínio da moralidade e que a moralidade não é meramente uma questão estritamente cognitiva ou emotiva, mas um amálgama entre as duas estruturas, apresentar-se-á a seguir a pesquisa de Jonathan Haidt (HAIDT, 2001, p. 814) sobre o funcionamento de como é feito o julgamento moral. Pesquisa essa que contribuiu muito para a retomada do realismo jurídico na descrição de como o sujeito se comporta nas decisões judiciais.

\subsubsection{O modelo sócio-intuicionista de Haidt}

Que os julgamentos morais são racionalizações post hoc de sentimentos que tem origem em algo anterior; que julgamentos morais são justificações que pouca relação tem com uma reflexão supostamente racional - era o que Nietzsche já indicava no "Crepúsculo dos Ídolos” (NIETZSCHE, 2006, p. 55). Indicação aforística essa que parece encontrar 
fundamentação nas pesquisas e estudos de Jonathan Haidt, o qual procura explicitar e explorar o papel das emoções nos julgamentos morais.

Impulsionado pelas contribuições em antropologia, psicologia evolutiva, neurociência e psicologia experimental, Haidt constrói sua perspectiva através de um modelo intuicionista social. Suas proposições são simples: em relação à intuição, Haidt parte do princípio que as intuições e emoções morais aparecem antes da reflexão e são as responsáveis pelos julgamentos morais; em relação à parte social, o autor explica que, na maioria dos casos, o raciocínio tem natureza instrumental, no sentido de justificar o julgamento que já foi feito intuitivamente, de forma que, nos julgamentos morais, a busca por razões se trata mais de uma busca por argumentos sustentadores de posições previamente fixados do que a busca pela verdade.

Haidt sugere que primeiro surge a intuição moral, depois o julgamento moral e, ao final, o raciocínio moral. Por intuição moral, o autor compreende o instante em que o fenômeno aparece na consciência através de um sentimento que não recorre a explicações lógicas, mas apenas sente se aquele fato é bom ou mau, agradável, indiferente ou desagradável. É a avaliação instintiva e inconsciente que antecede o julgamento moral. Este, por sua vez, parte de valores e virtudes consideradas importantes pela cultura, avaliando se tal ação e/ou caráter representa algo bom ou mau nos padrões pré-concebidos, se há ou não reconhecimento do fato particular nas normas suspostamente universais pertinentes à cultura na qual se está inserido. Nesse itinerário, o raciocínio moral seria um processo posterior, mais consciente, intencional e controlável: o julgador pondera sua intuição diante do fato e de seus juízos e preconcepções sobre o significado do fato em relação a sua cultura, de modo que, entre o significante intuitivo e o juízo significado, o julgador compreende a formação do signo enquanto composto por partes distintas e maleáveis. O raciocínio moral seria, portanto, uma percepção do conteúdo e do meio em que o conteúdo adquire significado, acompanhada da necessidade de justificação do julgamento anteriormente alcançado.

No modelo intuicionista social, Haidt descreve quatro conexões mais importantes. A primeira conexão estabelece um vínculo entre o que aparece na intuição e o julgamento moral consciente. É o momento em que se diz "isto é bom!" ou "isto é mau" sem que se calculem as variáveis presentes na circunstância. A segunda conexão lida com o raciocínio "post hoc”, em que são buscados argumentos para fundamentação do julgamento moral feito anteriormente. A terceira conexão ou o terceiro elo tem em vista a dimensão social da prática da moralidade e refere-se à ideia de persuasão racional. Haidt defende que, nesse ponto, o raciocínio moral 
consciente e verbal atua teologicamente, argumentando a favor de determinada posição no intuito de persuadir o próximo. Diferentemente da segunda conexão, neste terceiro elo a argumentação não se dá apenas por meio da linguagem lógica, mas procura dar ensejo a novas intuições aos ouvintes. A ideia do autor é que o melhor jeito de convencimento é a tentativa de provocar no ouvinte novas intuições, uma vez que os julgamentos morais são causados pela emoção. Se a afetividade desempenha um importante papel persuasivo, na quarta conexão, chamada de elo da persuasão social, ela aparece mais forte. Nesse ponto, Haidt destaca que o agir segundo o comportamento social, enquanto resposta ao contexto social, tem mais força do que se imagina. O convencimento pode ocorrer pela mera influência das opiniões de amigos e conhecidos, mesmo inexistindo argumentação.

Em relação a este último ponto, vale destacar um dos vários experimentos de Salomon Asch (ASCH, 1946, p. 258-290 e ASCH, 1952). Asch elaborou um teste simples cuja tarefa era identificar a linha correspondente à esquerda dentre as três linhas à direita.
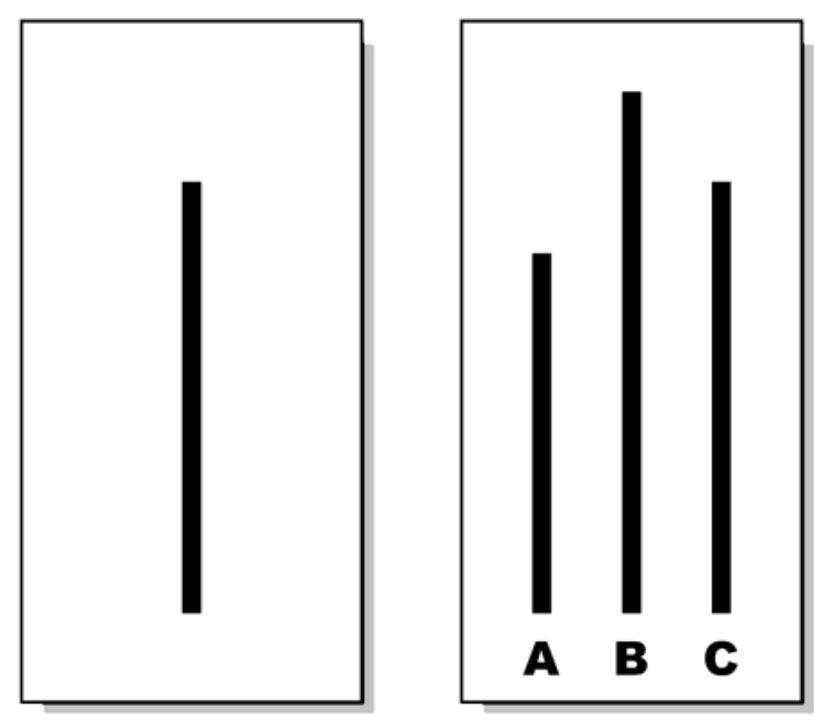

Observando a figura, fica óbvio que a linha $\mathrm{C}$ corresponde a imagem da esquerda. No entanto, o teste era feito da seguinte maneira: o sujeito testado dividia a sala com mais sete atores, treinados para previamente apontar uma resposta equivocada. Percebendo o cometimento de sucessivos erros por parte dos outros participantes, o testado procurava não ser diferente dos demais, errando sobre o que inicialmente considerava ululante.

A pesquisa contou com 123 voluntários, que eram sempre os últimos ou penúltimos a responder. Nos dois primeiros testes, os atores respondiam corretamente, a fim de que voluntário ficasse à vontade e confiante. No entanto, nos quatorze testes seguintes, os atores deveri- 
am errar doze, de forma que o sujeito testado não desconfiasse de uma armação premeditada. Considerando que a estimativa de respostas erradas nesse tipo de teste é de menos de 1 em 35 (menos de 3\%), os resultados foram assombrosos:

$.75 \%$ dos participantes escolheram a alternativa errada ao menos uma vez;

. 37\% dos voluntários erraram a maioria das respostas;

$.5 \%$ deles acompanharam a opção incorreta todas as vezes.

Fato é que a persuasão social, mesmo diante de análise de situações mais básicas e absurdas, impera como um dos fatores determinantes em ambientes coletivos de tomada de decisão.

Assim, esboçadas as quatro conexões básicas, componentes do que Haidt chama de núcleo modelo, o autor admite a existência de mais dois elos. Se o núcleo modelo articula o papel do raciocínio moral como justificador do julgamento moral perante os outros, o segundo momento retrata o uso privativo do raciocínio moral, ou seja, quando o raciocínio questiona suas próprias crenças, convicções e atitudes. Considerado pelo autor um processo feito raramente pela maioria das pessoas, esse segundo momento contém a conexão do julgamento fundamentado (quinta conexão) e a conexão da reflexão em contexto privado (sexta conexão).

A quinta conexão ou o elo do julgamento fundamentado reconhece que é possível chegar a um julgamento pelo uso da lógica, que vai além da intuição inicial. Nessa conexão, a racionalidade não está instrumentalmente a serviço das intuições, mas é senhora do tribunal do juízo. Mas não porque é autônoma e consciente de si mesmo, mas porque, segundo Haidt, tal conexão geralmente ocorre quando intuição inicial é fraca e a capacidade de processamento de informações é grande. Saliente-se também que, muitas vezes, alguns tipos de intuição podem ser bloqueados com base em determinados valores morais enraizados no sujeito, por exemplo, em casos de inclinações morais para rejeitar a possibilidade de aborto em qualquer circunstância, sob o axioma de que a vida nasce desde a concepção e de que o direito à vida é inviolável.

A sexta e última conexão refere-se à reflexão em contexto privado, indicando que as pessoas são capazes de criar, de forma espontânea, novas intuições, intuições que se opõem ao primeiro julgamento intuitivo. O seu principal mecanismo é o que Haidt chama de roletaking: é o se colocar no lugar do outro, de forma a vislumbrar determinado problema de uma perspectiva diferente, fato que potencialmente possibilitaria sentir novas intuições. Sem 
prescindir dos componentes sócios afetivos e intuitivos, em tal conexão, o julgador acionaria novas intuições ou até mesmo modificaria suas intuições anteriores a respeito do caso.

Portanto, para o modelo sócio-intuicionista social, tanto causas intuitivas quanto causas racionais, interferem no julgamento moral. A intuição é comum e é usada cotidianamente na geração de julgamentos morais rápidos e fáceis. $\mathrm{O}$ raciocínio moral só é utilizado quando há um conflito entre diversas intuições, quando a predisposição interpretativa não encontra clareza nas informações adquiridas.

O que Haidt conclui, em suma, é que a interpreta-se, geralmente, conforme as préferências ${ }^{3}$. Nada muito distante do que Gadamer indicou em Verdade e Método (GADAMER, 2008), ao evidenciar que o intérprete no ato de interpretar não pode ignorar as influências de suas próprias preconcepções e que, ao final, o ato interpretativo não se trata de superar inclinações preexistentes, mas situá-las ante um olhar crítico.

\footnotetext{
3 Se em Gadamer a interpretação válida é aquela em que o pesquisador, ciente de suas preconcepções e das circunstâncias que condicionam seus desvios de percepção, abdica das intuições repentinas e faz um uso disciplinado da razão em busca da verdade, Haidt indiretamente indica: a própria busca da verdade é condicionada por preferências intuitivas. Embora estar ciente das circunstâncias que cercam o "eu" é o primeiro passo para o exame (auto)crítico, é impossível desfazer-se o caráter intuitivo e social do próprio método.
} 
Fato é que a linguagem científica de Haidt renovou o que os realistas jurídicos já indicavam e repaginou a qualidade da argumentação em torno da vulnerabilidade do processo de decisão dos juízes. Perguntar sobre a possibilidade de uma decisão jurídica bem fundamentada torna-se indagar: é possível aos juízes deliberar consoante ao quinto e/ou sexto elo descritos no modelo? É possível aos juízes uma melhor qualidade na argumentação jurídica ou as decisões na maioria dos casos serão feitas de acordo com o núcleo modelo formado pelas quatro primeiras conexões?

Noel Struchiner e Marcelo Santini Brando acreditam (TRUCHINER e BRANDO, 2014, p. 200) que o elevado volume de trabalho a que os juízes estão submetidos, bem como a automatização da rotina do trabalho, seriam fatores que dificultariam o acionamento da deliberação moral das conexões cinco e seis. Salientam ainda que, por muitas vezes, o desenho institucional também não promove o diálogo. No Supremo Tribunal Federal (STF), por exemplo, cada ministro lê a sua decisão pronta na hora: não há momento anterior que os outros ministros possam participar da composição do voto. Alterar a decisão, portanto, torna-se demasiadamente trabalhoso, principalmente quando há inúmeros processos a espera de julgamento. No fim das contas, o juiz faria decisões inconsciente e automaticamente para depois funda- mentálas e justificá-las, advogando em torno de uma concepção previamente estabelecida. O raciocínio teria a função de confirmar a intuição. Assim, ao buscar razões para justificar o casamento homoafetivo, por exemplo, o juiz, ao contrário de ponderar argumentos, acessaria apenas um conjunto de crenças e regras que endossariam uma conclusão alcançada pela intuição.

Na construção dialética da decisão - tese, antítese e síntese -, a síntese já estaria contida potencialmente e muitas vezes evidenciada na forma como a tese é colocada. Concluir seria apenas confirmar ou conformar. Como salienta Sloterdijk, a miséria da dialética consiste em sustentar uma fantasia de vencedor (SLOTERDIJK, 2012, p.499).

Embora dando uma ênfase maior no sujeito e na forma como ele raciocina dentro de um ambiente, o realismo jurídico às vezes desdenha da capacidade do juiz articular a quinta e sexta conexão do modelo sócio-intuicionista e preocupa-se mais com a justificação dos erros e tendências do comportamento dos juízes do que com a busca de uma argumentação jurídica mais refinada e ciente de suas limitações. 
O problema em naturalizar o direito é a possibilidade de recair num determinismo que indiretamente anunciaria: "tudo compreender é tudo desculpar". Steven Pinker alerta sobre a perspectiva determinista que, muitas vezes, instrumentaliza conceitos biológicos para eximir a culpabilidade no plano jurídico. Tanto argumentos de determinismo genético - como dizer que o réu estuprou porque nele há um "gene do estupro" - quanto de determinismo ambiental - como a "defesa Twinkie ${ }^{4}$ - são utilizados como se as descobertas sobre a mente e cérebro estritamente requerem uma contração na esfera da responsabilidade e não uma expansão mas, compreender mais não poderia ser também responsabilizar mais?

Agora sob a roupagem científica, a argumentação do realismo jurídico pode meramente continuar a confirmar que, na aplicação/interpretação de uma lei ${ }^{5}$, a imagem refletida revela o contorno privado e, não raramente, soberbo (superbia ${ }^{6}$ ) dos agentes do poder. E que não haveria como ir além da racionalidade instrumental do direito, sendo inevitável que teorias sejam distorcidas e aplicadas consoante a personalidade do aplicador. Ao contrário de reforçar a dificuldade de se chegar nas conexões cinco e seis, a pergunta que o realismo deveria fazer é: como possibilitar ao juiz decidir consoante os elos cinco e seis? Ou: como evitar que a argumentação jurídica fique restrita ao núcleo modelo e, assim, aos sentimentos e racionalizações post hoc dos juízes?

Como foi dito, cada âmbito privilegia certo modo de ver os fenômenos e reforça uma característica do comportamento de decisão judicial, seja ele político, jurídico ou sóciointuicionista. Nesse sentido, constata-se que decidir é um ato complexo que envolve muitas variáveis e âmbitos infindáveis. Para finalizar, cabe pontuar dois aspectos que podem ser inseridos na análise realista do direito, mas que abrangem um âmbito amplo, que tangencia a análise comportamental das decisões jurídicas. O primeiro ponto é o papel da biologia nas decisões: o ser humano sendo um sujeito real, suscetível à fome, sede e frio, condicionado por circunstâncias fenotípicas e genéticas. O segundo ponto, por sua vez, capta a influência social no auto reconhecimento do sujeito ${ }^{7}$.

4 Julgamento em 1980 no qual um homem que matou a tiros duas autoridades em São Francisco teve sua defesa estruturada em torno do argumento de que ele fora afetado pela ingestão de muito açúcar ( Twinkie é a marca de um bolinho doce recheado). O réu foi absolvido, surgindo então a expressão "defesa twinkie" para designar uma defesa legal baseada em argumentos forçados.

5 Vale aqui destacar a crítica de Lênio Streck à distinção de Emilio Betti entre atribuição de sentido e interpretação. (STRECK, Lênio Luiz. Hermenêutica Jurídica e(m) Crise: Uma exploração hermenêutica da construção do Direito. Porto Alegre: Livraria do Advogado, 1999. pg. 88-93).

6 Santo Agostinho já identificava a superbia como uma espécie de querer conscientemente o que Deus não queria, como uma busca de privatização do que é comum, uma busca de autonomia e solipsismo que só é

possível a Deus. AGOSTINHO, Santo Agostinho. A verdadeira religião. IN: AGOSTINHO. A verdadeira

religião e o cuidado devido aos mortos. Tradução Ir. Nair de Assis Oliveira, CSA. São Paulo: Paulus, 2000. (XLVIII,93)

$7 \mathrm{O}$ direito detêm-se na análise da influência da sociedade em como deveria ser a decisão. A política envereda na influência da sociedade sobre os fins

almejados. O realismo, por sua vez, foca na influência da sociedade no sentido de como o juiz irá se comportar na decisão judicial. 
Quanto ao primeiro aspecto, recente estudo realizado em Israel, por exemplo, revelou que as circunstâncias fisiológicas influenciam as decisões dos juízes (TRUCHINER e CHRISMANN, 2014, p. 165-166). O objetivo da pesquisa era simples: entender como juízes decidem em casos em que presos requerem livramento condicional ou outras melhorias em suas condições prisionais. Os pesquisadores, então, coletaram dados de 1.112 audiências judiciais presididas por 8 juízes diferentes, possuindo uma média de 22 anos de experiência no exercício da função. O que os pesquisadores descobriram que o fator que melhor explicava as decisões dos juízes era a proximidade da decisão à hora do intervalo. $\mathrm{O}$ dia dos juízes continha dois intervalos, um para o lanche da manhã e outro para o almoço, fazendo com que os julgamentos acontecessem em 3 diferentes sessões. Assim que começava o dia, aproximadamente $65 \%$ dos pleitos eram concedidos, mas esse índice decaía de forma dramática, chegando a $0 \%$ de concessão para os pedidos próximos ao primeiro intervalo para o lanche. Assim, concluiu-se que a fadiga mental dos juízes permitia com que fosse adotada uma posição de manutenção do status quo, o que significa a preservação das condições prisionais do preso. As decisões que rejeitavam as solicitações e preservavam as condições prisionais continham menos palavras e as audiências eram mais curtas, e, sendo assim, exigiam menos dos juízes.

Se o nível de glicose é capaz de alterar uma decisão, a influência social no autoreconhecimento também não deixa de ser fator determinante, mesmo que de forma indireta. Os juízes, enquanto indivíduos e animais políticos, estão inseridos na inexorável busca por reconhecimento, reconhecimento esse tanto de caráter autônomo quanto vinculado à inserção nas formas de vida culturais específicas. Honneth, por exemplo, destaca, dentre os três modos de reconhecimento, a estima social (HONNETH, 2003). 
ESTRUTURA DAS RELAÇÔES SOCIAIS DE RECONHECIMENTO

\begin{tabular}{|c|c|c|c|}
\hline $\begin{array}{l}\text { Modos de } \\
\text { reconhecimento }\end{array}$ & $\begin{array}{l}\text { Dedicação } \\
\text { emotiva }\end{array}$ & $\begin{array}{l}\text { Respeito } \\
\text { cognitivo }\end{array}$ & $\begin{array}{l}\text { Estima } \\
\text { social }\end{array}$ \\
\hline $\begin{array}{l}\text { Dimensōes da } \\
\text { personalidade }\end{array}$ & $\begin{array}{l}\text { Natureza } \\
\text { carencial e afetiva }\end{array}$ & $\begin{array}{l}\text { Imputabilidade } \\
\text { moral }\end{array}$ & $\begin{array}{l}\text { Capacidades e } \\
\text { propriedades }\end{array}$ \\
\hline $\begin{array}{l}\text { Formas de } \\
\text { reconhecimento }\end{array}$ & $\begin{array}{l}\text { Relaçôes primárias } \\
\text { (amor, amizade) }\end{array}$ & $\begin{array}{l}\text { Relações jurídicas } \\
\text { (direitos) }\end{array}$ & $\begin{array}{l}\text { Comunidade } \\
\text { de valores } \\
\text { (solidariedade) }\end{array}$ \\
\hline $\begin{array}{l}\text { Potencial } \\
\text { evolutivo }\end{array}$ & & $\begin{array}{l}\text { Generalização, } \\
\text { materializaçāo }\end{array}$ & $\begin{array}{l}\text { Individualização, } \\
\text { igualização }\end{array}$ \\
\hline $\begin{array}{l}\text { Autorrelação } \\
\text { prática }\end{array}$ & Autoconfiança & Autorrespeito & Autoestima \\
\hline $\begin{array}{l}\text { Formas } \\
\text { de desrespeito }\end{array}$ & $\begin{array}{l}\text { Maus-tratos e } \\
\text { violação }\end{array}$ & $\begin{array}{l}\text { Privação de } \\
\text { direitos e exclusão }\end{array}$ & $\begin{array}{l}\text { Degradação e } \\
\text { ofensa }\end{array}$ \\
\hline $\begin{array}{l}\text { Componentes } \\
\text { ameaçados da } \\
\text { personalidade }\end{array}$ & Integridade física & Integridade social & $\begin{array}{l}\text { "Honra", } \\
\text { dignidade }\end{array}$ \\
\hline
\end{tabular}

Tabela contida em "Luta por reconhecimento" - pg. 211

Nesse ponto, a estima social não se fundamenta naquilo que o indivíduo é diante de suas relações intersubjetivas, mas naquilo que ele faz, na transformação que ele realiza na sociedade e sua recepção perante os membros do grupo. Se para a Igreja a fé sem obras é morta, para a estima social, a identidade do ser por si só não é capaz de garantir o reconhecer: um homem é determinado por aquilo que faz e aquilo que ele faz é medido pelo valor que tem em determinada sociedade. Segundo Honneth,

nas sociedades modernas, as relações de estima social estão sujeitas a uma luta permanente na qual os diversos grupos procuram elevar, com os meios da força simbólica e em referência às finalidades gerais, o valor das capacidades associadas à sua forma de vida (HONNETH, 2003, p. 207).

Nesse sentido, buscar a estima social na aprovação da sociedade civil, seja como apoio da opinião pública ou como a busca da concordância por segmentos específicos, faz parte a estrutura intersubjetiva de formação da identidade pessoal (HONNETH, 2003, p. 272). Através do reconhecimento do outro, o indivíduo reconhece a si mesmo: só imerso na sociedade, ele é capaz de buscar e compartilhar valores comuns, coparticipando do todo, mas se individualizando, sendo parte não absolutamente livre nem absolutamente vinculada ao todo. 


\section{Conclusão:}

3.1

Não restam dúvidas que se vive num sistema complexo. São muitas variáveis e muitos aspectos que incidem no momento da decisão, seja ela uma simples escolha, seja ela uma decisão jurídica. Procurou-se mostrar a presença de certas perspectivas (não exaustivas) e certos tipos de modelos de comportamento que figuram no cotidiano e na atitude tanto dos juízes no exercício profissional quanto das próprias pessoas.

3.2

Ivan Ilitch, à beira da morte, reflete sobre seu comportamento, sobre quando trabalhava como juiz. Para ascender na carreira, o jovem Ilitch estrategicamente opta por certas decisões. No entanto, em relação a outras, não abre mão de suas preferências ideológicas e interpretativas. Juridicamente, filia-se a uma teoria formal-legalista, em que se deve aplicar e interpretar o caso conforme a letra da lei - não há espírito, não há intenção, não há princípio que sobreponha o primado da norma: lei é lei mesmo quando a palavra aparentemente está morta. No entanto, embora o ordenamento jurídico prescreva a Ivan como ele deve julgar, antes mesmo de escutar os réus e testemunhas, ele intui a veracidade e a falsidade das falas ainda não ditas.

À beira da morte, o juiz russo reflete sobre suas inclinações, pela primeira vez. Pela primeira vez, tem consciência clara de como se comportou dentro daquele pequeno contex to que trabalhou a vida toda; pela primeira vez, vê a si mesmo com a clareza de quem passou a ver a vida com maior sentido, dentro da história dos homens e dentro das transformações do espírito; pela primeira vez, vê-se politicamente como parte de um todo que anseia por melhoras que vão além da mera vontade individual; pela primeira vez, coloca-se no lugar do outro e sente instituições nunca antes sentidas. À beira da morte, Ilitch conecta-se para além do ordinário e tem consciência de que há ali um modo, uma maneira de pensar e agir que, qualitativamente, é superior ao que foi pensado e agido. E mesmo que Ilitch experimentasse a si mesmo de maneira única e subjetiva ${ }^{8}$, sua relação com a compreensão do

8 A Judges guide to Neuroscience: A Concise introduction. University of California Santa Barbara : Sage Center for the Study of the Mind (2010). p 35 "So to the question, "Can neuroscience identify pain?" the answer is in theory yes. We can show its neural correlates in conscious human subjects but only using signal averaging and groups of subjects responding to applied stimuli. The signal is there, but it is small, and currently has not been shown to be useful in an individual at a single moment in time. It seems feasible that with longer periods of measurement or with improvements in signal to noise these problems can be overcome. It is important to point out that while the methods are robust, they are indirect. Pain depends upon activity in a specific set of neurons, their activation is sufficient to produce it, but in the end, the experience itself is subjective and therefore our methods to measure it are, of necessity, indirect".

Teorias do Direito e Realismo Jurídico | e-ISSN: 2525-9601| Minas Gerais | v. 1 | n. 2 | p. 1 - 19 | Jul/Dez. 2015. 
mundo transmutava-se. O orgulho, a vaidade e a ira tornavam-se percepções e sentimentos simplórios, conexões primárias de quem ainda não tinha consciência das várias perspectivas que compõem o sentido da vida.

\section{3}

É comum dizer que, com a ciência, o homem se propõe à dominação da natureza, fato que configuraria o sentido da técnica: ser a voz dos genes, daquilo que condiciona e determina, ser a voz da natureza e dos limites do corpo e do espírito. A neurociência, o mais novo e eficiente instrumento da ciência, mediria com precisão o comportamento e o raciocínio humano, podendo até, quem sabe, prever uma série de ações e ser o malhete nas decisões judiciais.

Mas o malhete é também instrumento e quem detém o poder da decisão é ainda o homem. A ciência não desnuda a natureza, mas revela apenas domínio inteligente da relação entre homem e natureza. Relação essa que não escapa de crítica, inclusive as próprias conclusões das pesquisas psicológicas apresentadas - que os juízes julgam conforme intuições que dão o resultado antes da ponderação dos fatos; que o indivíduo tem a tendência de julgar conforme a influência do grupo; que, na síntese, a preponderância da tese já estava indicada podem se voltar para elas mesmas, de modo a revelar que, antes mesmo das experiências, os resultados já eram esperados.

As técnicas e estudos científicos podem também ser instrumentalizados e, no final das contas, agirem como hieróglifos nas mãos de quem ainda detém um poder sem uma contraposição crítica. Por exemplo: diante do tribunal de júri, um especialista apresenta laudos e ressonâncias e diz que ali, na parte vermelha da imagem, está indicada uma lesão no córtex cerebral e conclui, ao final da exposição, que há 71,6\% de chance do réu não ter consciência do homicídio que lhe é imputado; na mão de um camponês é posto um fio e outros fios também lhe envolvem o corpo: o polígrafo, a sala isolada, a presença dos policiais e a circunstância de estar fora de casa sendo coagido, mesmo que não expressamente, a dizer a verdade sobre aquilo que supostamente presenciara. Situações que envolvem um poder simbólico da ciência e que podem ensejar um acriticismo por parte do julgador, de modo que este aceita o veredicto da ciência ou expõe justificativas com bases em números e dados que poderiam não corresponder certamente ao caso concreto. 
No caso do polígrafo e de circunstâncias que tendem a ser analisadas conforme um suposto padrão científico emerge a seguinte questão: até que ponto os tais pesquisas e experiências não se tornariam prescrições para simulações futuras? Treinar uma mentira, um timbre de voz, uma sequência diferente de piscar os olhos, a testa enrugando aparentemente de modo involuntário - tudo isso não configuraria um novo exercício de aparências para atuar em sociedade? Até que ponto a ciência, em sua suposta imunidade ideológica e em suas pesquisas comportamentais, não prescreveria uma nova aparência de comportamento?

Destas questões surgem novas perspectivas de análise comportamental - a análise do comportamento judicial que instrumentaliza teoria de decisão conscientemente, a análise do comportamento que tem consciência sobre diferentes perspectivas comportamentais, etc. - e mais âmbitos hão de surgir na medida em que se refina e argumentos são somados ao debate. Mas, para Ivan Ilitch, cabe a máxima: naturalizar não é preciso, ter consciência de que vários fatores cercam a decisão é preciso.

\section{REFERÊNCIAS BIBLIOGRÁFICAS:}

A Judges guide to Neuroscience: A Concise introduction. University of California Santa Barbara : Sage Center for the Study of the Mind (2010).

AGOSTINHO. A verdadeira religião e o cuidado devido aos mortos. Tradução Ir. Nair de Assis Oliveira, CSA. São Paulo: Paulus, 2000.

ASCH, S. Forming impressions of personality. Journal of Abnormal and Social Psychology, 41, 1946. 258-290.

ASCH, S. Social psychology. New York: Prentice Hall, 1952

DWORKIN, Ronaldo. Uma questão de principio. Tradução de Luís Carlos Borges. 2. ed. São Paulo: Martins Fontes, 2005. P. IX

DWORKIN, Ronald. O Império do Direito. Tradução de Jefferson Luiz Camargo. São Paulo: Martins Fontes, 2003. P. 475

EPSTEIN, L.; KNIGHT, J., The Choices Justices Make. Washington: CQ Press, 1998. p. xiii

FRIEDMAN, B. The Politics of Judicial Review. Texas Law Review v. 84, p. 257-337, 2005.

FERREIRA, Pedro Fernando de Almeida Nery. Como decidem os ministros do STF: pontos ideais e dimensões de preferências. Dissertação (Mestrado em Economia) — Universidade de Brasília, Brasília, 2013. 
FRANK, J. 2009 [1930]. Law and the modern. New Brunswick: Transaction. Pg. XXX

GADAMER, Hans-Georg. Verdade e método I: traços fundamentais de uma hermenêutica filosófica. Tradução de Flávio Paulo Meurer; revisão da tradução por Enio Paulo Giachini. 10 ed. Petrópolis, RJ: Vozes, 2008.

HAIDT, J. The Emotional Dog and Its Rational Tail: A Social Intuitionist Approach to Moral Judgment. Psychological Review, v. 108, n. 4, p. 814-834, 2001

HONNETH, Axel. Luta por reconhecimento: a gramática moral dos conflitos sociais. Tradução de Luiz Repa. São Paulo: Ed. 34, 2003

MARX e ENGELS. A ideologia alemã. Tradução de Luis Claudio de Castro e Costa. São Paulo: Martins Fontes, 1998. p. 03

NIETZSCHE. Crepúsculo dos ídolos. Tradução de Paulo César de Souza. São Paulo: Companhia das Letras, 2006

PINKER, Steven. Tábula Rasa: a negação contemporânea da natureza humana. Tradução de Laura Teixeira Motta. São Paulo: Companhia das Letras, 2004.

POSNER, R. How judges think. Cambrige: Harvard University Press, 2008. p. 10

SEGAL, Jeffrey A.; SPAETH, Harold J. (1993). The Supreme Court and the attitudinal model. New York: Cambridge University Press.

SLOTERDIJK, Peter. Ira e tempo: ensaio político-psicológico. Tradução de Marco Casanova. São Paulo: Estação Liberdade, 2012.

SLOTERDIJK, Peter. Crítica da razão cínica. Tradução Marco Casanova e outros. São Paulo: Estação Liberdade, 2012.

STRECK, Lênio Luiz. Hermenêutica Jurídica e(m) Crise: Uma exploração hermenêutica da construção do Direito. Porto Alegre: Livraria do Advogado, 1999.

TOLSTOI, Lev. A morte de Ivan Ilitch. Tradução de Boris Schnaiderman. São Paulo: Editora 34, 2006.

TRUCHINER, Noel ; BRANDO, M. S. . Como os juízes decidem os casos difíceis do direito?. In: Noel Struchiner; Rodrigo de Souza Tavares. (Org.). Novas fronteiras da teoria do direito: da filosofia moral à psicologia experimental. 1ed.Rio de Janeiro: POD/ Editora PUCRio, 2014 